\title{
Pesticides and Their Metabolites in Community Water-Supply Wells of Central and Western New York, August 1999
}

\author{
By David A.V. Eckhardt, Kari K. Hetcher, Patrick J. Phillips, and Todd S. Miller
}

The four compounds detected most frequently were the herbicides atrazine and metolachlor and their metabolites-deethylatrazine and metolachlor ESA. Concentrations of pesticides detected in this study, however, did not exceed State or Federal water-quality standards for drinking water.

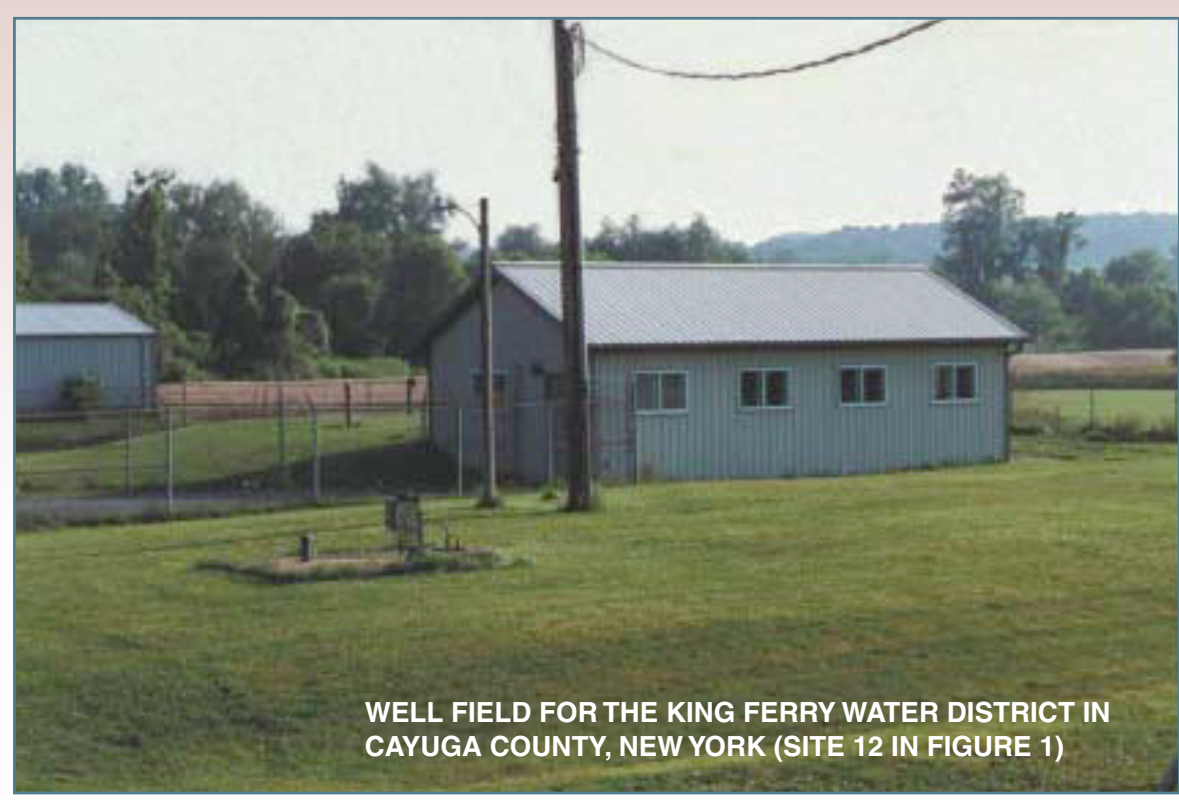

WELL FIELD FOR THE KING FERRY WATER DISTRICT IN CAYUGA COUNTY, NEW YORK (SITE 12 IN FIGURE 1)
$\mathbf{T}$ en pesticides and pesticide metabolites were detected in ground-water samples collected from each of 32 community water-supply (CWS) systems in central and western New York in August 1999. The sampling sites consisted of 30 wells that ranged from 23 to 120 feet in depth, and 2 springwater infiltration galleries. All wells tapped unconfined sand and gravel aquifers except one, which was completed in karstic limestone. These systems were selected because they were deemed vulnerable to pesticide contamination; accordingly, the results are not considered representative of all CWS systems in New York.

The samples were analyzed for 60 pesticides. Twentyfour of the 32 samples contained at least one pesticide, and one sample contained eight pesticides or pesticide metabolites. New York State and Federal water-quality standards were not exceeded in any sample collected in this study.

All pesticides detected in the CWS wells are a specific class of herbicides that are used to control broadleaf weeds and undesirable grasses in agricultural fields, lawns, and other areas that require control of vegetation. The four compounds detected most frequently were the herbicides atrazine and metolachlor and their metabolites - deethylatrazine and metolachlor ESA. Maximum concentrations of the four compounds ranged from 0.088 micrograms per liter $(\mu \mathrm{g} / \mathrm{L})$ for deethylatrazine to $3.58 \mu \mathrm{g} / \mathrm{L}$ for metolachlor ESA. 


\section{INTRODUCTION}

Community water-supply systems throughout the United States are under increasing threat of contamination from agricultural and urban-use pesticides. In 1999, the U.S. Geological Survey (USGS), in cooperation with the New York State Department of Environmental Conservation, began a ground-water-monitoring program to document the occurrence and distribution of pesticides in 32 community water-supply (CWS) wells in western and central New York (fig. 1) that were deemed vulnerable to pesticide contamination. These wells (1) tap relatively shallow unconfined aquifers that are susceptible to contamination from pesticides applied to land surface, (2) induce flow to the well from nearby surface-water bodies that contain pesticides, or (3) are within a half-mile radius of areas where pesticides are used, such as croplands or urban areas. Wells that tap confined aquifers, or that are not in agricultural or urban areas, were considered less vulnerable to pesticide contamination and were not sampled.

The 60 pesticides monitored in this study are commonly used herbicides and insecticides and their metabolites. All samples collected in this study consisted of "raw" (untreated) water; therefore, the results do not necessarily represent the chemical characteristics of community drinking water after treatment. Also, the sampling sites were selected for their vulnerability to contamination and, therefore, are not considered to represent ground-water quality throughout New York State.

This report summarizes data on the concentration and frequency of detection of the 60 pesticides in samples from the 32 sites sampled in this study, relates the detection of selected herbicides to the predominant land use (agricultural or urban) near the sampled wells and to the potential for induced infiltration from nearby surfacewater bodies, and relates the concentration of the detected compounds to Federal and State drinking-water standards.

\section{STUDY METHODS}

The USGS collected samples from the 32 CWS wells (fig. 1) in August 1999. Well depths ranged from 23 to 120 feet below land surface; two infiltration galleries that collect spring water also were sampled (sites 3 and 5, table 1). All wells tapped unconfined sand or gravel aquifers, except for one (site 8, table 1), which was completed in karstic limestone.

The CWS sites were classified into two categories: those whose water consists solely of precipitation that has infiltrated through the soil at land surface, and those whose water is likely to be derived partly through induced infiltration from a nearby surface-water body (table 1). The probability of induced infiltration was identified from hydrogeologic data and chemical and biological analyses of the well water. The classification of some of the wells is considered tentative, however, where data were insufficient. Wells that are potentially affected by induced infiltration were identified through the following information:

- Simulations by numerical flow models that indicated ground-water flow from a surface-water body to a CWS site;

- A loss of streamflow within the zone of influence of a nearby CWS pumping well, as indicated by streamdischarge measurements;

- Downward infiltration of stream water through a streambed near a CWS well, as indicated by declines in hydraulic heads in wellpoints placed in the streambed;

- Chemical and biological analyses of samples from the CWS wells for specific constituents (for example, algae, giardia, and cryptosporidium) that are indicative of surface water quality; or

- A surface-water body within 200 feet of a CWS well.

Each site also was classified according to the predominant land use (agricultural or urban) within a halfmile radius of the well or spring. Land-use interpretations were based on mapping data generated from satellite imagery collected in 1994 (U.S. Geological Survey, 1997).

Samples were collected and processed by the methods of Shelton (1994) and were analyzed by the USGS for 60 pesticides and pesticide metabolites through methods described by Zaugg and others (1995), Meyer and others (1993), and Ferrer and others (1997). The detection limits of the methods used to analyze the samples ranged from 0.001 to $0.2 \mu \mathrm{g} / \mathrm{L}$ (table 2). The analytical method devised by Zaugg and others (1995), developed in cooperation with the U.S. Environmental Protection Agency, detects some of the most commonly used pesticides in the nation. 


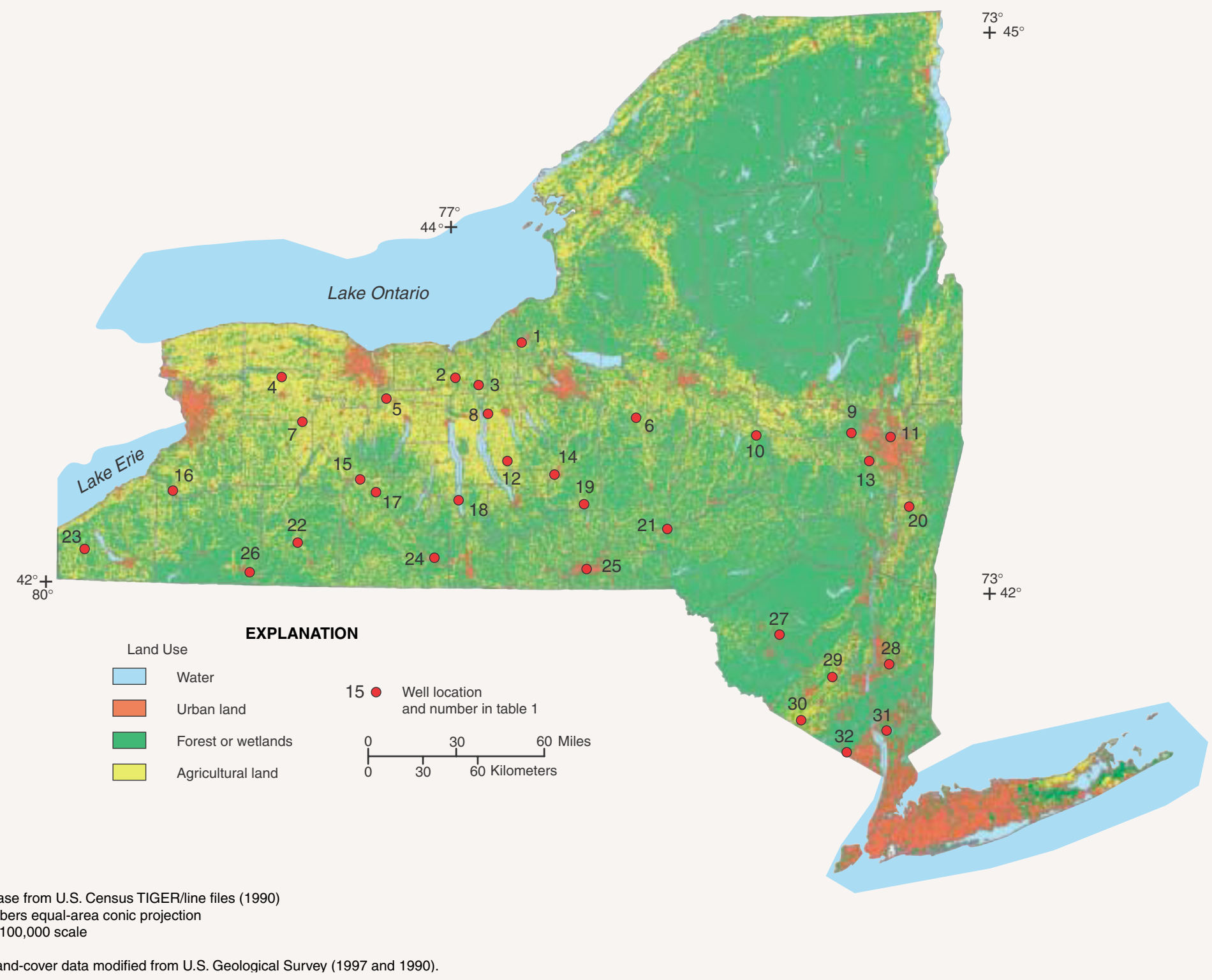

Figure 1. Land use and location of sites sampled in western and central New York

\section{PESTICIDES AND THEIR METABOLITES IN COMMUNITY WATER-SUPPLY WELLS}

Of the 60 pesticides for which the samples were analyzed, 10 were detected, all of which were herbicides (fig. 2). At least one herbicide or metabolite was detected in 24 of the 32 samples, and 8 different herbicides or metabolites were detected in one sample (site 17, table 1). The pesticides detected in the CWS wells are a specific class of herbicides that are used to control broadleaf weeds and undesirable grasses in agricultural fields, lawns, and other areas that require control of vegetation. These herbicides are highly soluble, but their toxicity to humans is relatively low compared to that of insecticides (Ware, 1983).

Pesticides in surface water and ground water often occur as mixtures of two or more compounds (Kolpin and others, 1998a). In this study, 21 (66 percent) of the 32 samples contained 2 or more pesticides or pesticide metabolites, but no State or Federal drinking-water standards for pesticides were exceeded. This percentage is higher than the national average for two or more compounds in a single well-water sample (25 percent) but is not representative of the State's 
Table 1. Land use and infiltration of surface water at 32 community water-supply wells in central and western New York, August 1999 [Locations are shown in fig. 1.]

\begin{tabular}{|c|c|c|c|c|c|c|c|c|}
\hline \multirow{2}{*}{$\begin{array}{l}\text { Number } \\
\text { in } \\
\text { fig. } 1\end{array}$} & \multirow[b]{2}{*}{ Community } & \multirow[b]{2}{*}{$\begin{array}{l}\text { USGS station } \\
\text { number }^{1}\end{array}$} & \multirow[b]{2}{*}{$\begin{array}{l}\text { County } \\
\text { well no. }\end{array}$} & \multirow[b]{2}{*}{ Local identifier } & \multirow{2}{*}{$\begin{array}{l}\text { Well depth } \\
\text { (feet below } \\
\text { land surface) }\end{array}$} & \multicolumn{2}{|c|}{ Land use ${ }^{3}$} & \multirow{2}{*}{$\begin{array}{l}\text { Affected } \\
\text { by induced } \\
\text { infiltration } 4\end{array}$} \\
\hline & & & & & & Urban & $\begin{array}{l}\text { Agri- } \\
\text { cultural }\end{array}$ & \\
\hline 1 & Fulton, City of & 431815076234001 & OW 454 & Well 2A & 70 & 46 & 19 & yes \\
\hline 2 & Clyde, Village of & 430647076552901 & WN 560 & Well 2 & 55 & 0 & 94 & no \\
\hline 3 & Savannah, Village of & 430527076453401 & WN 370 & Infiltration gallery & 20 & 0 & 77 & yes \\
\hline 4 & Elba, Village of & 430503078104201 & GS 188 & Well 3 & 61.3 & 6 & 81 & no \\
\hline 5 & Victor, Village of & 425853077240801 & OT1132 & Infiltration gallery & spring & 51 & 23 & no \\
\hline 6 & Morrisville, Village of & 425342075382601 & M 225 & Well 2 & 40 & 41 & 26 & no \\
\hline 7 & Pavillion, Town of & 425142078020802 & GS 189 & Well 1 & 27 & 0 & 84 & yes \\
\hline 8 & Union Springs, Village of & 425056076412201 & CY 53 & South well ${ }^{5}$ & 120 & 39 & 49 & no \\
\hline 9 & Schenectady, City of & 424912073591801 & SN 130 & Well 2 & 62 & 38 & 11 & yes \\
\hline 10 & Cherry Valley, Village of & 424742074453201 & OG 310 & Well 2 & 28 & 25 & 60 & yes \\
\hline 11 & Clifton Park, Town of & 424710073473801 & SA1499 & Well 4 & 32 & 14 & 2 & no \\
\hline 12 & $\begin{array}{l}\text { Genoa, Town of } \\
\text { (King Ferry Water District) }\end{array}$ & 424025076321001 & CY 10 & Well 1 & 31 & 19 & 43 & yes \\
\hline 13 & Voorheesville, Village of & 423919073553801 & A 650 & Well 4 & 64 & 66 & 1 & no \\
\hline 14 & Cortlandville, Town of & 423454076124001 & C 355 & Well 3 & 63 & 54 & 18 & no \\
\hline 15 & Wayland, Village of & 423418077353401 & SB 381 & Well 1 & 44 & 46 & 41 & no \\
\hline 16 & Cattauragus Indian Reservation & 423001078565401 & E1084 & Reservation well & 28 & 9 & 67 & no \\
\hline 17 & Cohocton, Village of & 423001077300801 & SB 224 & Well 2 & 73 & 45 & 23 & yes \\
\hline 18 & Hector, Hamlet of & 422937076531401 & SY 402 & Well 2 & 33 & 6 & 2 & yes \\
\hline 19 & Marathon, Village of & 422633076020801 & C 452 & Well 1 & 28 & 42 & 15 & yes \\
\hline 20 & Kinderhook, Village of & 422328073413304 & CB1040 & Well 4 & 36 & 27 & 34 & yes \\
\hline 21 & Sidney, Village of & 421851075235901 & D 501 & Well 2 & 95 & 48 & 13 & yes \\
\hline 22 & Belmont, Village of & 421404078023001 & AG 502 & Wells 3 and 4 & 23 & 4 & 75 & yes \\
\hline 23 & Sherman, Village of & 420926079360001 & CU 861 & Well 2 & 39 & 28 & 52 & no \\
\hline 24 & Corning, City of & 420850077030701 & SB 380 & Well 9 & 60 & 72 & 4 & yes \\
\hline 25 & Johnson City & 420647075584201 & BM 210 & Well 3 & 89 & 58 & 1 & yes \\
\hline 26 & Olean, City of & 420406078241701 & CT 632 & Well 37 & 61 & 20 & 56 & no \\
\hline 27 & Woodbourne, Town of & 414504074355301 & SV 534 & Well 3 & 45 & 26 & 22 & no \\
\hline 28 & Wappinger, Town of & 413520073511201 & DU1254 & Well 5 & 38.5 & 72 & 10 & no \\
\hline 29 & Montgomery, Village of & 413119074150801 & $\mathrm{O} 2269$ & Holt well 3 & 50 & 32 & 41 & no \\
\hline 30 & Pine Island Water District & 411736074275101 & $\mathrm{O} 2268$ & Well 2 & 66 & 21 & 63 & no \\
\hline 31 & Croton-on-Hudson, Village of & 411301073515401 & WE 511 & Well 1 & 65 & 11 & 0 & yes \\
\hline 32 & Suffern, Village of & 410659074093701 & RO 494 & Well 4 & 120 & 50 & 0 & yes \\
\hline
\end{tabular}

1 Station numbers assigned by U.S. Geological Survey.

2 County well numbers assigned by U.S. Geological Survey. Prefix designates county; number is county sequential number.

${ }^{3}$ Land use (USGS, 1997) expressed as percentage of area within a half-mile radius of well.

4 Potential for induced infiltration from nearby surface-water body.

5 Bedrock well in Onondaga Limestone Formation.

ground water because all wells were chosen specifically for their vulnerability to pesticide contamination and, thus, do not represent a random sampling.

The herbicide metolachlor was detected in samples from 8 of the 32 wells. The concentration in 7 samples was below $0.02 \mu \mathrm{g} / \mathrm{L}$, although the concentration in one (site 2 , table 1) was $0.28 \mu \mathrm{g} / \mathrm{L}$. The relatively high concentration of metolachlor at this well is attributed to the high percentage of agricultural land around the well. Metolachlor is used as weed control on crops such as corn, soybeans, potatoes, and hay, and is the parent compound of metolachlor ESA and metolachlor OA. These two metabolites were detected in samples from 14 of the 32 wells, and the concentrations in all but one of the samples were above $0.1 \mu \mathrm{g} / \mathrm{L}$. Site 2 had the highest concentration of metolachlor ESA $(3.58 \mu \mathrm{g} / \mathrm{L})$, which was the maximum concentration of any compound detected in this study.

The herbicide atrazine, which is used in agricultural and urban areas, was detected in samples from 15 of the 32 wells; the maximum concentration was $0.097 \mu \mathrm{g} / \mathrm{L}$. Atrazine has been the pesticide detected most frequently in ground-water studies in the past; this is attributed to its extensive use (Barbash and Resek, 1996). Deethylatrazine, a metabolite of atrazine, was detected in samples from 19 of the 32 wells; the maximum concentration was 0.088 $\mu \mathrm{g} / \mathrm{L}$. Every sample in which atrazine was detected also 
Table 2. Detection limits for the 60 pesticide and pesticide metabolites for which samples were analyzed, August 1999.

[ESA, ethanasulfonic acid. OA, oxanilic acid. Detection-limit concentrations (in parentheses) are in micrograms per liter.]

\begin{tabular}{|c|c|c|c|c|c|c|c|}
\hline Pesticide & $\begin{array}{l}\text { Detection } \\
\text { limit }\end{array}$ & Pesticide & $\begin{array}{l}\text { Detection } \\
\text { limit }\end{array}$ & Pesticide & $\begin{array}{l}\text { Detection } \\
\text { limit }\end{array}$ & Pesticide & $\begin{array}{l}\text { Detection } \\
\text { limit }\end{array}$ \\
\hline
\end{tabular}

A. Gas Chromatography/Mass Spectrometry - US Geological Survey National Water Quality Laboratory, Denver, Colorado

\begin{tabular}{|c|c|c|c|c|c|c|c|}
\hline Acetochlor & $(0.002)$ & Deethylatrazine* & $(0.002)$ & Metolachlor & $(0.002)$ & Pronamide & $(0.003)$ \\
\hline Alachlor & $(0.002)$ & Diazinon & $(0.002)$ & Metribuzin & $(0.004)$ & Propachlor & $(0.007)$ \\
\hline alpha-HCH & $(0.002)$ & Dieldrin & $(0.001)$ & Molinate & $(0.004)$ & Propanil & $(0.004)$ \\
\hline Atrazine & $(0.001)$ & Disulfoton & $(0.017)$ & Napropamide & $(0.003)$ & Propargite & $(0.013)$ \\
\hline Benfluralin & $(0.002)$ & EPTC & $(0.002)$ & $p, p^{\prime}-\mathrm{DDE}^{*}$ & $(0.006)$ & Simazine & $(0.005)$ \\
\hline Butylate & $(0.002)$ & Ethalfluralin & $(0.004)$ & Parathion & $(0.004)$ & Tebuthiuron & $(0.010)$ \\
\hline Carbaryl & $(0.003)$ & Ethopropos & $(0.003)$ & Parathion-methyl & $(0.006)$ & Terbacil & $(0.007)$ \\
\hline Carbofuran & $(0.003)$ & Fonofos & $(0.003)$ & Pebulate & $(0.004)$ & Terbufos & $(0.013)$ \\
\hline Chlorpyrifos & $(0.004)$ & Lindane & $(0.004)$ & Pendimethalin & $(0.004)$ & Thiobencarb & $(0.002)$ \\
\hline Cyanazine & $(0.004)$ & Linuron & $(0.002)$ & cis-Permethrin & $(0.005)$ & Tri-allate & $(0.001)$ \\
\hline DCPA & $(0.002)$ & Malathion & $(0.005)$ & Phorate & $(0.002)$ & Trifluarlin & $(0.002)$ \\
\hline 2,6-Diethylanaline* & $(0.003)$ & Methyl azinphos & $(0.001)$ & Prometon & $(0.017)$ & & \\
\hline
\end{tabular}

B. High Performance Liquid Chromatography - USGS Organic Research Laboratory, Lawrence, Kansas

$\begin{array}{llllll}\text { Acetachlor ESA* } & (0.2) & \text { Alachlor ESA* } & (0.2) & \text { Hydroxyatrazine* }(0.2) & \text { Metolachlor OA* (0.2) } \\ \text { Acetachlor OA* } & (0.2) & \text { Alachlor OA* } & (0.2) & \text { Metolachlor ESA* (0.2) } & \end{array}$

C. Gas Chromatography/Mass Spectrometry - USGS Organic Research Laboratory, Lawrence, Kansas

\begin{tabular}{|c|c|c|}
\hline Ametryn & $(0.05)$ & Deisopropy \\
\hline Cyanazine amide* & $(0.05)$ & Prometryn \\
\hline
\end{tabular}

* metabolite product

contained deethylatrazine. Atrazine and deethylatrazine were the most commonly detected pesticides found together in this study, as well as in a previous study of pesticides in ground water throughout the United States (Kolpin and others, 1998a).

The herbicide alachlor was not detected in any sample, but its metabolite alachlor ESA was found in 3 well samples, and its metabolite alachlor OA was found in 1 well sample; all four concentrations exceeded $0.3 \mu \mathrm{g} / \mathrm{L}$. Prometon, which is used for weed control along utility and transportation rights-of-way and at electricity substations, was detected in samples from 5 of the wells sampled (sites 12, 17, 19, 22, 25, table 1). Sites 17, 19, and 25 are in urban areas; this may account for the prometon detections. Sites 12 and 22 are in agricultural areas, however, and the reason for detection is unknown. None of the prometon concentrations exceeded $0.05 \mu \mathrm{g} / \mathrm{L}$. The herbicides simazine and metribuzin were each detected at one site (sites 18 and 17, respectively) at concentrations less than $0.05 \mu \mathrm{g} / \mathrm{L}$.

\section{COMPARISON WITH LONG ISLAND STUDIES}

A similar study of ground water from 50 wells in Suffolk County on Long Island (Phillips and others, 1999a), followed the methods used in this study and found 25 pesticides. Five insecticides were detected, 3 of which were in more than 20 percent of the samples. The 7 pesticides detected at the highest frequency and at the highest concentrations were the herbicides atrazine, metolachlor, simazine, and tebuthiuron; the metolachlor metabolites metolachlor ESA and metolachlor OA; and the simazine and atrazine metabolite deisopropylatrazine. The maximum concentrations of these 7 pesticides ranged from 1 to $30 \mu \mathrm{g} / \mathrm{L}$. Drinking-water standards were exceeded in samples from several wells- the State and Federal Maximum Contaminant Levels (MCLs) for simazine were exceeded in 2 samples; the New York State Class GA standards for dieldrin were exceeded in 8 samples, and those for simazine in 6 samples. As in the present study of CWS sites in western and central New York, all samples 


\section{BENEFITS OF LOW DETECTION LIMITS}

The use of analytical methods with low detection limits for the analysis of many pesticides in this study resulted in a higher frequency of detection than would be obtained from less sensitive methods. The use of analytical methods with such low detection limits not only aids in the identification of trace amounts of pesticides in water, it allows researchers to discern relations between pesticide exposure and human health. These low detection limits also increase the likelihood that pesticides not detected in the analysis are truly absent from the water samples.

Almost all concentrations of prometon, metolachlor, simazine, metribuzin, deethylatrazine, and atrazine were well below $0.05 \mu \mathrm{g} / \mathrm{L}$, the detection limit commonly used in routine pesticide monitoring. The low detection limits used in this study revealed deethylatrazine in more than half of the samples, and atrazine in almost half of the samples. Metolachlor was detected in one quarter of the samples.

\begin{tabular}{|l|l|}
\hline & Metabolites are formed when a parent compound degrades, typically \\
through the action of bacteria within the soil zone to which the \\
parent compound is applied; thus the concentrations of metabolites in \\
ground water commonly are higher than that of the parent compound. \\
Some metabolites can form from the degradation of more than \\
one compound; for example, deisopropylatrazine can form from the \\
degradation of either atrazine or simazine (Thurman and others, 1994). \\
Other metabolites are specific to only one parent compound; for \\
example, metolachlor ESA and metolachlor OA are derived solely \\
from the parent compound metolachlor. \\
Sampling for herbicide metabolites in this study was motivated in \\
part by findings in other studies that have shown metolachlor ESA, \\
metolachlor OA, and deisopropylatrazine to be commonly present in \\
ground water in agricultural areas (Kolpin and others, 1997; Kolpin and \\
others, 1998b; Phillips and others, 1999a; Phillips and others, 1999b). \\
Concentrations of these metabolites often equaled or exceeded those \\
of the parent compound. Few, if any, Federal water-quality standards \\
have been established for these metabolites. \\
\end{tabular}

consisted of untreated water from wells in vulnerable settings and, therefore, may not represent the quality of treated water provided for public consumption.

The results of the present study differ from those of the 1998 Long Island study (Phillips and others, 1999a) in that (1) no insecticides were detected, (2) herbicides were detected less frequently and at lower concentrations, and (3) no State or Federal drinking-water standards were exceeded. Insecticides tend to be detected at lower frequencies and at lower concentrations in agricultural areas than in urbanized areas, such as Long Island (Kolpin and others, 1998a; Gilliom and others, 1999). Simazine and tebuthiuron, which are used on Long Island for weed control in urban areas, were detected in 44 and 22 percent of the Suffolk County wells, respectively. In contrast, simazine was detected in only one sample (site 18), which is in a vineyard area where simazine is used, and tebuthiuron was not detected. The herbicide metabolite deisopropylatrazine, which was detected in 20 percent of the Suffolk County water samples, was not detected in any of the samples collected in the present study, probably because its main parent compound (simazine) is not widely used in central and western New York. In general, relatively few urban-use pesticides were detected in samples from the CWS wells because the areas around these wells are predominantly agricultural and rural. 


\section{EFFECTS OF LAND USE ON PESTICIDE CONCENTRATIONS}

A statistical comparison of the presence of certain pesticides and pesticide metabolites in water from the CWS wells with land use around the wells indicates a correlation (fig. 3). This type of comparison can provide an indication of the sources of these pesticides. The comparisons are complicated by several factors, however, such as (1) the distance that ground water has traveled since pesticides reached the water table, (2) the directions of ground-water flow, (3) changes in land-use patterns since the pesticides entered the ground water, and (4) the effects of ground-water pumping on flow paths to the well; for example, if flow paths intersect nearby surface-water bodies, pumping can induce infiltration of surface water, which in turn can contain contaminants such as pesticides.

Concentrations of atrazine and metolachlor, which were detected in more than 25 percent of the CWS samples, were compared with the amounts of agricultural and urban land within a half-mile radius around each well. Atrazine and metolachlor concentrations increase as the percentage of agricultural land increases, and decrease as the percentage of urban land increases (fig. 3). The common use of metolachlor for control of grasses and broad-leaf weeds in crops would explain the observed linear correlation of metolachlor concentration with agricultural land use. The use of atrazine in urban and residential areas as well as in agricultural areas weakens the observed correlation with agricultural land use (fig. 3).

\section{Community Water-Supply Wells in New York, August 1999 CONCENTRATION, IN MICROGRAMS PER LITER}

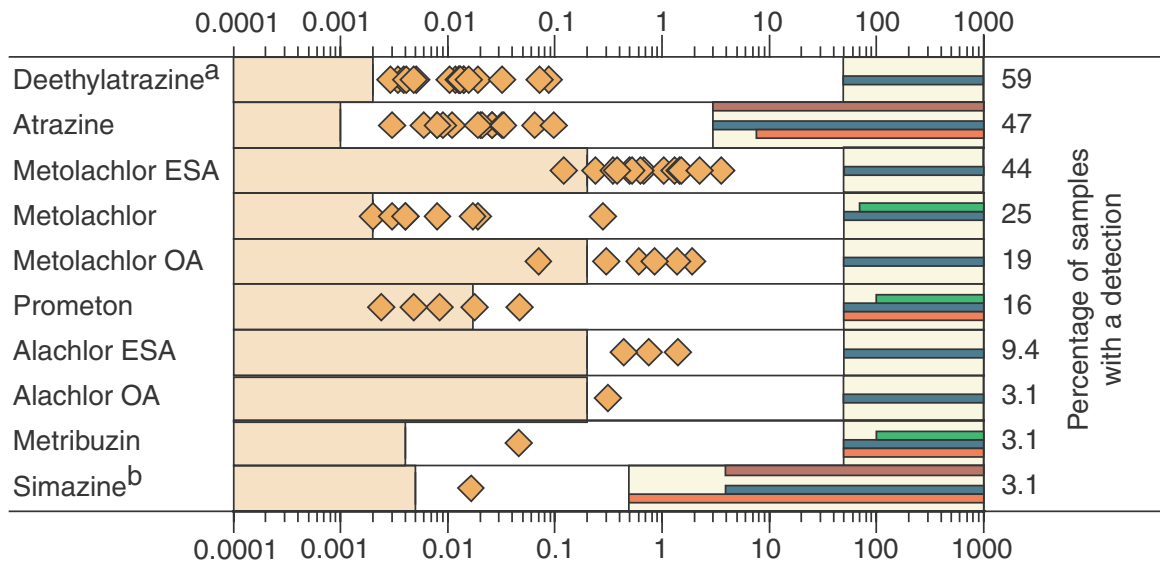

\section{EXPLANATION}

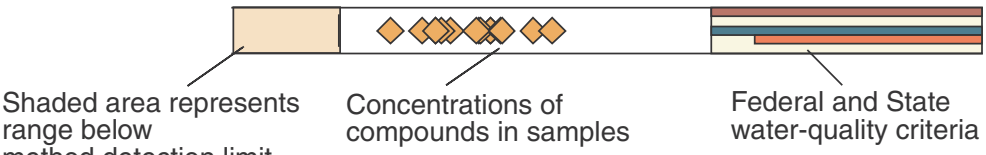

range below

method detection limit

(estimated concentration)

Federal Maximum Contaminant Level (MCL)
Federal Lifetime Health Advisory (HA)
New York State Maximum Contaminant Level
New York State Class GA

a Estimated concentration because of low or inconsistent recovery

b New York State Surface Water Standard equals class GA standard

NOTE:

Percentage values and constituent range include quantifiable detections below method detection limits. Percentage values may not be comparable between pesticides because (1) detection limits differ and (2) the number of quantifiable detections below the method detection limit differ. New York State regulations include general standards of $50 \mu \mathrm{g} / \mathrm{L}$ for Unspecified Organic Contaminants and $5 \mu \mathrm{g} / \mathrm{L}$ for Principal Organic Contaminants. New York State water-quality standards are based on New York State Department of Environmental Conservation (1998) and New York State Department of Health (1998). Federal water-quality standards are based on U.S. Environmental Protection Agency (1996). Federal MCL standards are based on a one-year average concentration of more than one sample.

Figure 2. Concentration of pesticides detected in samples collected from 32 community water-supply wells in August 1999, and percentage of samples in which each pesticide was detected.

\section{EFFECTS OF INDUCED INFILTRATION ON PESTICIDE CONCENTRATIONS}

Some wells are surrounded by only small areas of agricultural and urban land but contain moderate to high concentrations of atrazine. For example, the land surrounding site 18 is only 6 percent urban and 2 percent agricultural (table 1), but the atrazine concentration was higher there than in several wells with more agricultural or urban land nearby 


\section{FEDERAL AND NEW YORK STATE WATER-QUALITY STANDARDS USED IN THIS STUDY}

This report compares the concentrations of pesticides detected in this study with State and Federal standards listed below. The standards are based on concentrations of individual pesticides and do not account for mixtures of pesticides. Websites with additional information on the Federal standards are included.

- Federal Maximum Contaminant Levels (MCLs) are the maximum permissible concentration of a contaminant in water that is delivered to any user of a public water system under provisions of the Federal Safe Drinking Water Act (U.S. Environmental Protection Agency, 1996).

MCLs are set as close as feasible to the concentration at which no known or anticipated adverse effects on health are expected to occur. Federal MCLs are based on a 1-year average concentration of more than one sample.

http://www.epa.gov/safewater/glossary.html

- Federal Health Advisory values (HA) are established by the U.S. Environmental Protection Agency under the Safe Drinking Water Act where adequate scientific information is available but an MCL has not yet been officially set. http://www.epa.gov/OST/Tools/dwstds.html

- New York State Maximum Contaminant Levels are established under the New York State Department of Health Public Water Systems Regulations (New York State Department of Health, 1998). State MCLs are similar to Federal MCLs but include general standards that apply to any organic chemical contaminant that does not have a Federal MCL. These include a standard of (1) $5 \mu \mathrm{g} / \mathrm{L}$ for Principal Organic Contaminants (POCs), (2) $50 \mu \mathrm{g} / \mathrm{L}$ for any Unspecified Organic Contaminant (UOC), and (3) $100 \mu \mathrm{g} / \mathrm{L}$ for the total of POCs and UOCs.

- New York State Class GA Standards are set by the New York State Department of Environmental Conservation, on the basis of health-based or esthetic-based procedures established in New York State regulations (New York State Department of Environmental Conservation, 1998) to protect ambient ground waters that are a potential source of drinking water. Class GA Standards are used for protection of the resource, rather than as a maximum allowable limit for water consumption and use. Accordingly, these risk-based values are typically more stringent than drinking-water MCLs. 


\section{A. AGRICULTURAL LAND}

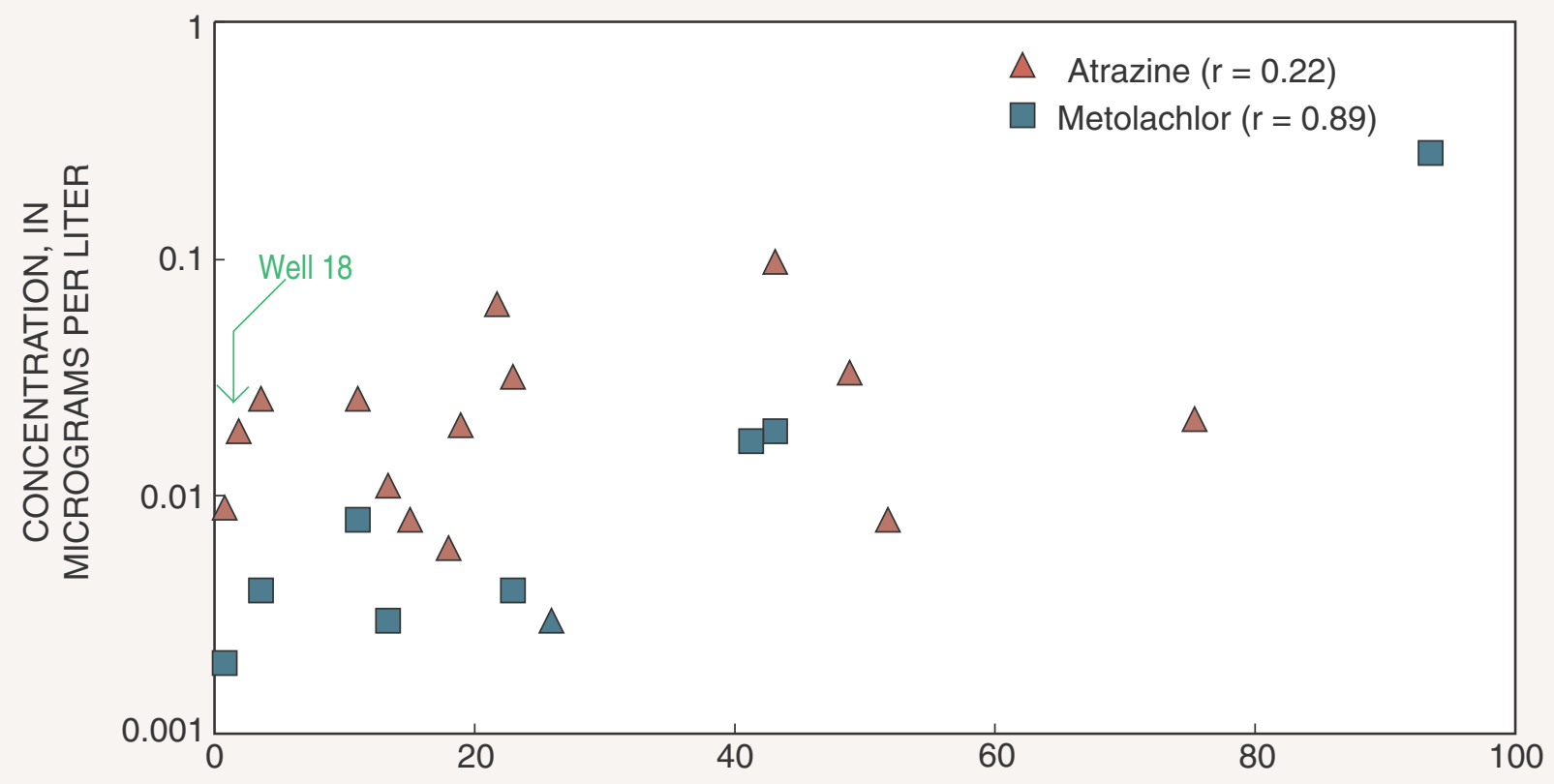

AMOUNT OF AGRICULTURAL LAND WITHIN HALF-MILE

RADIUS OF WELL, IN PERCENT

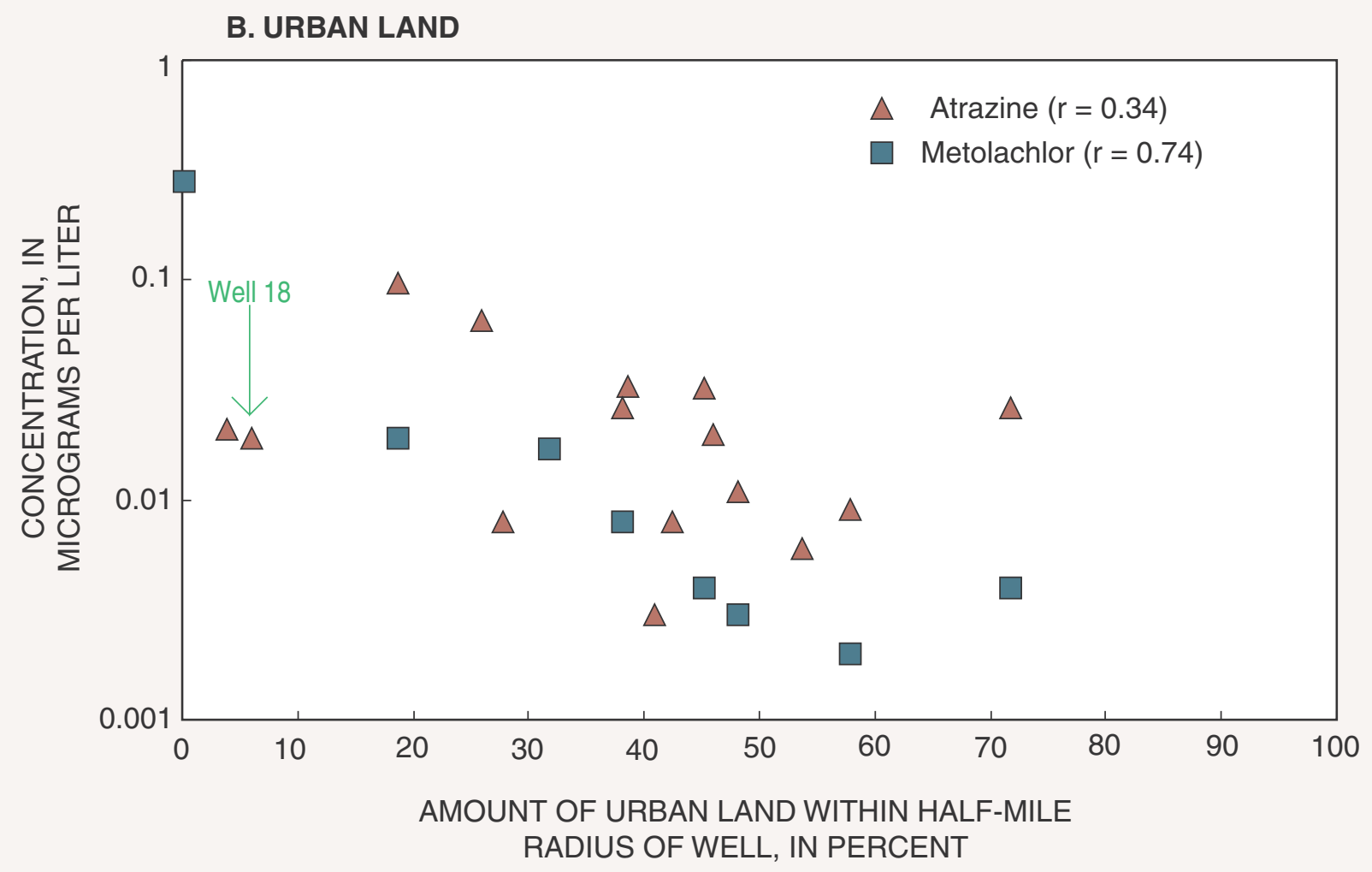

Figure 3. Atrazine and metolachlor concentrations in samples from community water-supply wells in New York, 1999, and percentage of agricultural and urban land within a half-mile radial area around the wells. (Site 18 discussed in text) 

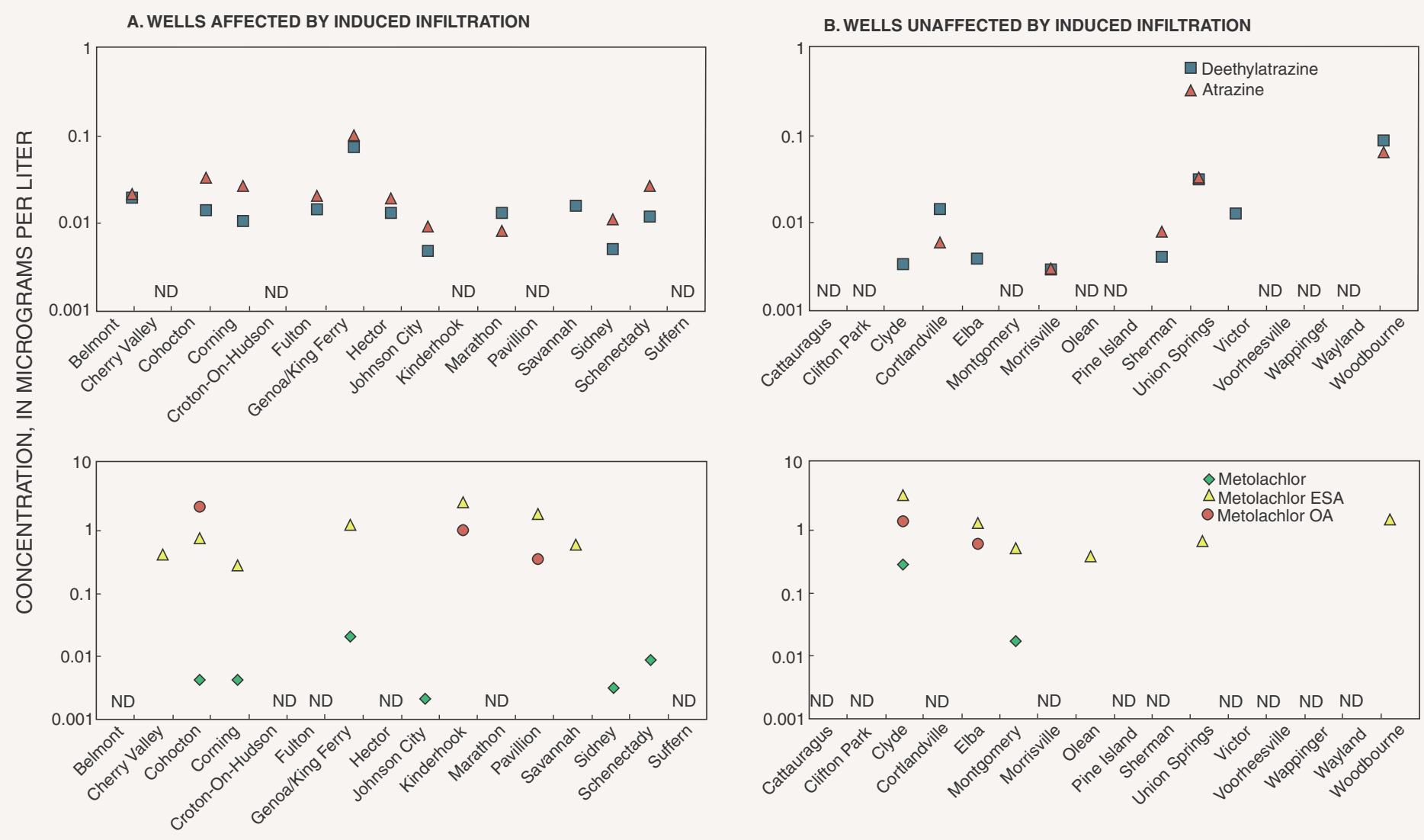

SITE NAME

Figure 4. Concentration of atrazine, metolachlor, and their metabolites in water samples from community water-supply wells in New York State, 1999. A. Wells with water that is potentially affected by induced infiltration of surface water. B. Wells with water derived mainly through direct infiltration of precipitation through land surface. (ND = not detected)

(fig. 3). This result is attributed to the induced infiltration of water from Seneca Lake by pumping at site 18.

The infiltration of lake water has a greater effect on well-water quality than does the land use near this well; hence, basinwide land-use effects can complicate statistical correlations of pesticide concentrations with land use at the nearby well sites that are affected by infiltration of surface water.

The CWS well samples were collected in early August 1999, after a period of storm runoff in early July, to obtain ground water that was likely to contain pesticides derived from induced infiltration of surface water. The herbicides typically detected at the wells-atrazine and metolachlor - are generally applied to fields in late spring to midsummer and can be flushed from the soil into streams and lakes by rain that falls soon after application. As a result, the concentrations of pesticide parent compounds in downstream surface-water bodies can exceed those of the metabolites (Eckhardt and others, 1999; Phillips and others, 1998; 1999b). More than half of the CWS wells sampled in this study are within 500 feet of streams, rivers, or lakes, and pumping of the wells may induce infiltration from those surface-water bodies. The 3 months that preceded the August 1999 sampling were exceedingly dry in western New York, however; thus, little pesticide was flushed into surface-water bodies. Accordingly, the results of this study do not reflect the effects of induced infiltration that would be expected in wetter years.

Atrazine was detected in 10 of the 16 wells classified as affected by induced infiltration of surface water, and its metabolite deethylatrazine was detected in 11 of these wells. Atrazine concentrations exceeded those of its metabolite in 9 of the 10 wells at which both compounds were detected (fig. 4A). Metolachlor was detected in 6 of the 16 affected wells, and metolachlor ESA was detected in 7 of these wells. The metolachlor concentration exceeded that of its metabolites in 3 of the 6 wells.

Samples from the 16 wells classified as unaffected by induced infiltration had slightly fewer detections, 
and typically lower concentrations, of atrazine and deethylatrazine than those from the induced-infiltration wells (fig. 4B). The concentrations of metabolites at all but one of these wells exceeded those of the parent compounds, an indication that the water at these wells is derived primarily from precipitation that infiltrates through the soil, where metabolites are formed through the contact of parent compounds with soil bacteria.

The correlation between well classification (presence or absence of induced infiltration) and (1) pesticide

\section{SUMMARY}

In August 1999, a ground-water sample was collected from each of 32 community water-supply (CWS) systems throughout central and western New York State that were deemed vulnerable to pesticide contamination. These wells tap relatively shallow unconfined aquifers that are susceptible to contamination from pesticides applied to land surface, induce flow from nearby surface-water bodies that contain pesticides, or are within a half-mile radius of areas where pesticides are used, such as croplands or urban areas. The results of this study, therefore, are not considered to represent ground-water quality throughout New York State.

Of the 60 pesticides for which the samples were analyzed, 10 were detected, all of which were herbicides. Of the 32 samples analyzed, 24 contained at least one pesticide or metabolite, and one contained 8 compounds. The four compounds detected most frequently were the herbicides atrazine and metolachlor and their metabolites-deethylatrazine and metolachlor ESA. Concentrations of the pesticides detected in this study did not exceed State or Federal water-quality standards.

The results from the present study differ from those of a similar 1998 study in Suffolk County on Long Island, in that this study detected (1) no insecticides, (2) herbicides at lower frequencies and at lower concentrations, and (3) no concentrations that exceeded State or Federal drinking occurrence or (2) ratio of parent compounds to metabolites does not apply at some wells. For example, the Savannah well (site 3, table 1), which was classified as an induced infiltration well, did not contain any parent compounds and only moderate concentrations of metabolites (fig. 4A). Conversely, the Clyde well (site 2 ), which is not affected by induced infiltration, contained relatively high concentrations of metolachlor and its two metabolites (fig. 4B); this is attributed to the high percentage of agricultural land surrounding this well.

water standards. These differences are attributed mainly to the high percentage of urban land around the Long Island wells, and the predominance of agricultural and rural land surrounding the central and western New York wells.

A statistical comparison of the presence of certain pesticides in water from the CWS wells with land use within a half-mile radius of the wells indicates a correlation. The concentrations of atrazine and metolachlor (two pesticides frequently used on agricultural fields) increase in proportion to the percentage of agricultural land surrounding the well sites, and decrease in proportion to the percentage of urban land surrounding the sites.

The relation between land use and pesticide concentration is complicated by the induced infiltration of water from nearby surface-water bodies into wells. Pesticide parent compounds (mainly atrazine and metolachlor) can be directly flushed from agricultural fields into surface-water bodies by storm runoff soon after pesticide application. In this study, concentrations and detection frequencies of pesticide compounds were generally larger in wells classified as affected by induced infiltration than in wells classified as unaffected by induced infiltration. Surface-water quality can be affected by land use throughout the entire watershed; therefore, the pesticide concentrations in well water affected by induced infiltration may be inconsistent with land use in the area immediately surrounding the well.

\section{ACKNOWLEDGMENT}

This study would not have been possible without the cooperation of the different towns, cities, and villages that allowed us to sample their water supplies. We also thank Ron Entringer and Paul Kaczmarczyk of the New York State Department of Health, who provided useful information and comments during the study. 
Barbash, J.E., and Resek, E.A., 1996, Pesticides in ground water-Distribution, trends, and governing factors: Chelsea, Mich., Ann Arbor Press, 588 p.

Eckhardt, D.A., Kappel, W.M., Coon, W.F., and Phillips, P.J., 1999, Pesticides and their metabolites in Cayuga Lake and its tributaries, New York, in Morganwalp, D.W., and Buxton, H.T., (eds.), U.S. Geological Survey Toxic Substances Hydrology Program — Proceedings of the Technical Meeting, Charleston, SC, March 1999: U.S. Geological Survey Water Resources Investigations Report 99-4018B, p. 395-403.

Ferrer, Imma, Thurman, E.M., Barcelo, Damia, 1997, Identification of ionic chloroacetanilide herbicide metabolites in surface and groundwater by HPLC/MS using negative ionspray: Analytical Chemistry, v. 69, p. 4547-4553.

Gilliom, R.J., Barbash, J.E., Kolpin, D.W., and Larson, S.J., 1999, Testing water quality for pesticide pollution: Environmental Science and Technology, v. 33, p. 164-169.

Kolpin, D.W., Barbash, J.E., and Gilliom, R.J., 1998a, Occurrence of pesticides in shallow ground water of the United States-Initial results from the National WaterQuality Assessment Program: Environmental Science and Technology, v. 32, p. 558-567.

Kolpin, D.W., Kahlkhoff, S.J., Goolsby, D.A., Sneck-Fahrer, D.A., and Thurman, E.M., 1997, Occurrence of selected herbicides and herbicide degradation products in Iowa's ground water, 1995: Ground Water, v. 35, p. 679-687.

Kolpin, D.W., Thurman, E.M., and Linhart, S.M., 1998b, The environmental occurrence of herbicides-The importance of degradates in ground water: Archives of Environmental Contamination and Archives of Environmental Contamination and Toxicology, v. 35, p. 385-390.

Meyer, M.T., Mills, M.S., and Thurman, E.M., 1993, Automated solid-phase extraction of herbicides from water for gas chromatographic-mass spectrometric analysis: Journal of Chromatography, v. 629, p. 55-59.

New York State Department of Environmental Conservation, 1998, Water quality regulations for surface and groundwaters: Title 6 chapter X (parts 703.5, table 1), 10 NYCRR Subpart 5-1, Albany, N.Y.
New York State Department of Health, 1998, New York State Health Department Public Water Systems Regulations [effective March 12, 1998]: Albany, N.Y. Phillips, P.J., Wall, G.R., Eckhardt, D.A., Freehafer, D.A., and Rosenmann, Larry, 1998, Pesticide concentrations in surface waters of New York State in relation to land use, 1997: U.S. Geological Survey Water Resources Investigations Report 98-4104, 7 p.

Phillips, P.J., Eckhardt, D.A., Terracciano, S.A., and Rosenmann, Larry, 1999a, Pesticides and their metabolites in wells of Suffolk County, New York, 1998: U.S. Geological Survey Water Resources Investigations Report 99-4095, $12 \mathrm{p}$.

Phillips, P.J., Wall, G.R., Thurman, E.M., Eckhardt, D.A., and Vanhoesen, J., 1999b, Metolachlor and its metabolites in tile drain and stream runoff in the Canajoharie Creek watershed: Environmental Science and Technology, v. 33, no. 20, p. 3531-3537.

Shelton, L.R., 1994, Field guide for collecting and processing stream-water samples for the National WaterQuality Assessment Program: U.S. Geological Survey Open-File Report 94-455, 42 p.

Thurman, E.M., Meyer, M.T., Mills, M.S., Zimmerman, L.R., Perry, C.A., 1994, Formation and transport of deethylatrazine and deisopropylatrazine in surface water: Environmental Science and Technology, v. 28, p. 2267-2277.

U.S. Environmental Protection Agency, 1996, Drinking water regulations and health advisories: Washington D.C., U.S. Environmental Protection Agency, Office of Water, EPA 822-B-96-002, Oct. 1996, 11 p.

U.S. Geological Survey, 1997, Digital map file of land cover for the U.S. Environmental Protection Agency Region II, version 1: Sioux Falls, S.D., EROS Data Center, 1:100,000-scale, 1 sheet.

Ware, G.W., 1983, Pesticides-Theory and application: New York, W.H. Freeman, 308 p.

Zaugg, S.D., Sandstrom, M.W., Smith, S.G., and Fehlberg, K.M., 1995, Methods of analysis by the U.S. Geological Survey National Water Quality Laboratory-Determination of pesticides in water by C-18 solid-phase extraction and capillary-column gas chromatography with selective-ion monitoring: U.S. Geological Survey Open-File Report 95-181, 49 p.

\section{For Additional Information Contact:}

Subdistrict Chief

U.S. Geological Survey

30 Brown Road

Ithaca, New York 14850

\section{Copies of this report can be purchased from:}

U.S. Geological Survey

Branch of Information Services

Box 25286

Denver, C0 80225 